\title{
The Effect Of Social Media On The Choice Of Dental Patients: A Cross-Sectional Study In The City Of Jeddah, Saudi Arabia
}

This article was published in the following Dove Press journal: Patient Preference and Adherence

\author{
Abdullah Alalawi (D) \\ Hamad Aljuaid \\ Zuhair S Natto \\ Department of Dental Public Health, \\ Faculty of Dentistry, King Abdulaziz \\ University, Jeddah, Saudi Arabia
}

Correspondence: Zuhair S Natto Department of Dental Public Health, Faculty of Dentistry, King Abdulaziz University, PO BOX 403II, Jeddah 2I499, Saudi Arabia

Tel +966I2503620037

Email znatto@kau.edu.sa
Background and purpose: In the past few years, social networking sites have received great attention in the health field by health practitioners and researchers, as well as health centers. The aim of this research is to investigate the important factors of patients (male or female) when choosing a dental practice, and the effectiveness of a social media presence for a dental practice to engage with and obtain new patients, as well as the return on investment of social media marketing.

Patients and methods: 400 random sample patients in the city of Jeddah, Saudi Arabia participated. The inclusion criteria were the following: patients above the age of 16 years, patients who have previously visited the dentist, patients who use social networking sites, patients who are fluent in Arabic or English, and patients residing in Saudi Arabia. The questionnaire was divided into four main sections and included questions revolving around the person's use of social networking sites and the factors influencing his/her decision to choose his/her dentist, especially those related to social networking sites.

Results: The data collection entailed capturing 400 patients' responses; the majority of participants were between the age of 18 and 25 years old, and more than half of them were males $(54.4 \%)$. The majority of patients had a social media account $(95.3 \%)$, however, $4.7 \%$ of patients did not have a specific social media account, but they still used social media to get updated. We also found that the most popular platform to use for patients was Snapchat, at $75.1 \%$, followed by Instagram, at $73.8 \%$. Females tended to be more interested in having a social media platform to inform them about a dental practice and almost all factors.

Conclusion: The presence of the dentist in social networking sites and correct interaction with them is important to reach new patients and communicate with his/her former patients.

Keywords: social media, dentistry, patient prospective, practice, marketing

\section{Introduction}

Social networking sites are locations on the Internet through which people can communicate with each other, as well as provide and share information, photos, videos and private messages. ${ }^{1}$ Examples of the most popular social networking sites are Facebook, Twitter, Instagram, Snape Chat, LinkedIn, YouTube, WhatsApp, and other sites that increase the size of their following continuously. ${ }^{2}$ These sites are popular among citizens and residents of the Middle East, especially in Saudi Arabia. According to Global Media Sight's statistics in May 2018, the number of Internet users in Saudi Arabia increased to 30 million in the beginning of 2018, and the penetration reached $91 \%$ in the country. ${ }^{3,4}$ 
In the past few years, social networking sites have received great attention in the health field by health practitioners and researchers, as well as health centers. ${ }^{5}$ It has become a reliable tool for some researchers to publish questionnaires about their health research and has become an essential means of spreading health awareness among members of society. ${ }^{6}$ Because of this popularity, social networking sites have become a means of marketing health services provided by health facilities and private medical clinics. ${ }^{7}$

In addition, some dentists from different fields of specialization rely on social networking sites to share their cases, such as cosmetic dentistry, dental surgery, orthodontics, periodontics, dental implants, etc., where they are published as pictures or videos, and many dentists and dental clinics have relied on social networking sites to market their services. ${ }^{8}$

Moreover, there are no studies in Saudi Arabia showing the relationship between patients' gender and social media sites and their effect on the decision to choose a dentist, so the aim of this research is to investigate the important factors for patients (male or female) when choosing a dental practice, and how social media may engage and obtain new patients, compared to conventional marketing, for a dental practice.

\section{Materials And Methods}

\section{Sample}

In this study, 400 random sample patients in the city of Jeddah, Saudi Arabia, participated. The Inclusion criteria was as follows: patients above the age of 16 years, patients who have previously visited the dentist, patients who use social networking sites, patients who are fluent in Arabic and English, and patients residing in the city of Jeddah. Moreover, the exclusion criteria are illiterate patients, mentally retarded patients, and patients who have not visited any dentist. To participate in the study, in the beginning of a questionnaire, we gave an introduction and we clarified the main purpose of our research, the topics that will asked in this questioner, and when you press "Accept" will join with us as a participant in this research, and we have ensured that everyone involved has filled the written informed consent. Consequently, ethical approval was released to begin this research (REC No 104-10-18) from The Research Ethics committee, Faculty of Dentistry, King Abdulaziz University.

\section{Questionnaire}

The research questionnaire was prepared from previous research and was modified in accordance with the objectives of our research. ${ }^{9}$ The questionnaire was divided into four main sections. The first section began by defining our objectives from this study and recommending the participant to choose the most accurate answer in his/her opinion. The second part of the research questionnaire consisted of questions on demographic information and about the personal use of social networking sites. The third section's questions concerned the relationship between the patient and his/her dentist on the social networking sites, such as his/her favorite social networking sites to follow the dentist, as well as the participant's interest in evaluating his/her dentist and sharing his/her opinion. The questions in the last section are to understand the most important factors for the patient when choosing a dentist and the factors that are most important to him/her when looking at the account of his/her dentist on social networking sites.

\section{Validity}

The questionnaire was tested or face and content validity. The survey was distributed to 10 individuals with expertise in some aspect of the subject matter. These individuals included dental consultants, postgraduate students in dentistry, general dentists, dental interns, as well as people from the general public. They were asked to rate the importance of each question using a five-point Likert scale $(1=$ very important, $2=$ important, $3=$ moderately important, $4=$ of little importance, $5=$ not important). To determine if each of the items should be included in the questionnaire, the 10 individuals were asked to rate the items based on: $0=$ no, $1=$ unsure, and $2=$ yes. For face validity, the same survey was administered to five dental students, and each of them assessed the clarity of questions and ability of respondents to understand each question.

\section{Reliability Testing}

For test-retest reliability, 10 individuals were asked to complete the survey and then they repeated the survey a second time after a one-week period. The results of the survey were compared for consistency by calculating kappa statistics. We modified the survey based on the results of face and content testing, as well as the results of the reliability testing.

\section{Survey Distribution}

The survey had 15 questions in total. Some of these questions were divided into sub-questions. The estimated time to complete the survey is around 7 mins. The Google form 
platform was used because it is available with no requirement for the participants to register. In addition, it is accessible on many devices, such as smartphones, tablets, or desktop computers. This questionnaire was distributed in an electronic format to the randomized samples, based on the criteria mentioned above, in several areas of Jeddah and during a public event on Oral and Dental Health Awareness (AFLA TOBSERON) presented by a group of dental interns from King Abdulaziz University in Jeddah.

\section{Statistical Plan \& Sample Size}

The sample size was estimated using the $\mathrm{G}^{*}$ power program (version 3.1.9). Assuming a proportion of 0.5 , desired precision of estimate was 0.05 , and at a $95 \%$ confidence level, based on results reported in the literature and during face and reliability steps 14 and 15 . A sample size of 385 subjects was adequate to obtain a Type I error rate of $5 \%$ and a power of $80 \%$. To account for potential dropout, an initial sample size of around 400 was recruited.

Descriptive statistics (counts/percentages for categorical variables) were calculated. Statistical significance between the two groups was assessed via chi square or fisher exact test. P-values less than 0.05 were considered significant. SAS Version 9.3 was used in the analysis.

\section{Results}

\section{Sample Characteristics}

The data collection resulted in 401 patients' responses. The majority of participants were between the age of 18 and 25 years $(51.1 \%)$, and more than half of them were males (54.4\%). Table 1 summarizes some of participants' personal demographics, social media use, gender, and age. However, 4.7\% (19/401) of patients didn't have a specific social media account, but they still use the social media to get updated. In the other hand, the majority had a social media account (95.3\%). In Table 1, the most popular platform to use for patients was Snapchat (75.1\%), followed by Instagram (73.8\%), and the least-popular social media platform was Linkedin (11.2\%).

\section{Patients' Opinions}

Table 2 was about patients' opinions as to whether or not it is necessary for a dental practice to have a social media presence or not. Our results in Table 2 also showed that most of the participants strongly agreed about having a social media platform in the dental practice $(53.4 \%)$, and it is effective to obtain new patients $(55.1 \%)$. However,
Table I Demographic Characteristics Of Study Sample

\begin{tabular}{|l|l|}
\hline Variable & $\mathbf{N}(\%) \mathbf{N}=\mathbf{4 0}$ I \\
\hline Age & \\
I8-25 & $205(51.1)$ \\
$26-35$ & $124(30.9)$ \\
$36-45$ & $4 I(10.2)$ \\
$46+$ & $31(7.7)$ \\
\hline Gender & \\
Male & $218(54.4)$ \\
Female & $183(45.6)$ \\
\hline Personal social media account & \\
Yes & $382(95.3)$ \\
No & $19(4.7)$ \\
\hline Social networking sites use & \\
Snapchat & $301(75.1)$ \\
Instagram & $296(73.8)$ \\
Twitter & $249(62.1)$ \\
Facebook & $130(32.4)$ \\
Linkedln & $45(11.2)$ \\
Other & $57(14.2)$ \\
\hline
\end{tabular}

females tended to be more interested in having a social media platform for a dental practice $(61.3 \%$ vs $52.9 \%)$, as the results have revealed (Table 2).

\section{Factors Related To Choosing A Dental Practice}

Table 3 shows some variables about the most important factors for the patient when it comes to choosing a dental practice. The facilities and technology (69.1\%), followed by NHS service $(65.8 \%)$, were the most important, while the presence of social media was the least important $(15.2 \%)$, as shown in the Figure 1. Females tended to be more concerned about these factors than males (Table 3).

\section{Factors Related To Looking At A Social Media Account For A Dental Practice}

Regarding Table 4, we were looking for the most important factors for the participants when it comes for visiting a social media account for a dental practice. It showed us that the most important factors were the positivity of the reviews and the qualifications of the dentist (56.4\% each), and the least important factors were the awards (24.4\%), followed by number of likes (25.9\%) (Figure 2).

The findings of Table 4 revealed that females were more interested in the positivity of reviews, before-and-after images, and the qualifications of the dentist $(p<0.05)$. In 
Table 2 Frequency And Percentages Of Patients' Opinions Regarding Dental Practice And Social Media

\begin{tabular}{|c|c|c|c|c|}
\hline Variable & $\begin{array}{l}\text { All } N(\%) \\
N=40 \text { I }\end{array}$ & $\begin{array}{l}\text { Male N(\%) } \\
N=218\end{array}$ & $\begin{array}{l}\text { Female } N(\%) \\
N=183\end{array}$ & $P$ value \\
\hline $\begin{array}{l}\text { Dental practice should have an online presence } \\
\text { Strongly disagree } \\
\text { Disagree } \\
\text { Agree } \\
\text { Strongly agree }\end{array}$ & $\begin{array}{l}21(5.2) \\
46(11.5) \\
96(23.9) \\
214(53.4)\end{array}$ & $\begin{array}{l}\text { II (5.4) } \\
28(13.7) \\
57(27.9) \\
108(52.9)\end{array}$ & $\begin{array}{l}10(5.8) \\
18(10.4) \\
39(22.5) \\
106(61.3)\end{array}$ & $0.023 *$ \\
\hline $\begin{array}{l}\text { Social media presence is effective to engage and obtain new patients } \\
\text { Strongly disagree } \\
\text { Disagree } \\
\text { Agree } \\
\text { Strongly agree }\end{array}$ & $\begin{array}{l}16(3.9) \\
46(11.5) \\
94(23.4) \\
221(55.1)\end{array}$ & $\begin{array}{l}\mathrm{II}(5.4) \\
28(13.7) \\
58(28.4) \\
107(52.5)\end{array}$ & $\begin{array}{l}5(2.9) \\
18(10.4) \\
36(20.8) \\
114(65.9)\end{array}$ & $0.002^{*}$ \\
\hline $\begin{array}{l}\text { The return on investment of social media marketing when compared to } \\
\text { conventional marketing for a dental practice? } \\
\text { Strongly disagree } \\
\text { Disagree } \\
\text { Agree } \\
\text { Strongly agree }\end{array}$ & $\begin{array}{l}20(4.9) \\
57(14.2) \\
106(26.4) \\
194(48.4)\end{array}$ & $\begin{array}{l}9(4.4) \\
37(18.1) \\
60(29.4) \\
98(48)\end{array}$ & $\begin{array}{l}\text { II (6.4) } \\
20(11.6) \\
46(26.6) \\
96(55.5)\end{array}$ & $0.025^{*}$ \\
\hline
\end{tabular}

Note: ${ }^{*} p$ value $<0.05$

Table 3 Frequency And Percentage Of Factors Related To Choosing A Dental Practice

\begin{tabular}{|c|c|c|c|c|}
\hline Variable & All $N(\%) ~ N=40$ I & Male $\mathbf{N}(\%) \quad N=218$ & Female $N(\%) N=\mid 83$ & $P$ value \\
\hline Social media presence & & & & $0.03 I^{*}$ \\
\hline Not important & $|4|(35.2)$ & $80(39.2)$ & $61(35.3)$ & \\
\hline Important & $175(43.6)$ & $95(46.6)$ & $80(46.2)$ & \\
\hline Very important & $6 I(15.2)$ & $29(14.2)$ & $32(18.5)$ & \\
\hline Quality of website & & & & $0.038^{*}$ \\
\hline Not important & $77(19.2)$ & $45(22.1)$ & $32(18.5)$ & \\
\hline Important & $169(42.1)$ & $91(44.6)$ & $78(45.1)$ & \\
\hline Very important & $15 \mathrm{I}(37.7)$ & $68(33.3)$ & $63(36.4)$ & \\
\hline Online reviews & & & & $0.039 *$ \\
\hline Not important & $38(9.5)$ & $24(I 1.8)$ & $14(8.1)$ & \\
\hline Important & $136(33.9)$ & $73(35.8)$ & $63(36.4)$ & \\
\hline very important & $203(50.6)$ & $107(52.5)$ & $96(55.5)$ & \\
\hline NHS service & & & & $0.009 *$ \\
\hline Not important & $16(3.9)$ & $12(5.9)$ & $4(2.2)$ & \\
\hline Important & $97(24.2)$ & $57(27.9)$ & $40(23.1)$ & \\
\hline Very important & $264(65.8)$ & $135(66.2)$ & $129(74.6)$ & \\
\hline Facilities and technologist & & & & $0.020 *$ \\
\hline Not important & $17(4.2)$ & $12(5.9)$ & $5(2.9)$ & \\
\hline Important & $83(20.7)$ & $48(23.5)$ & $35(20.2)$ & \\
\hline Very important & $277(69.1)$ & $144(70.6)$ & $133(76.9)$ & \\
\hline Recommendations from friendslfamily & & & & $0.046^{*}$ \\
\hline Not important & $31(7.7)$ & $20(9.8)$ & $\mathrm{II}(6.4)$ & \\
\hline Important & $143(35.7)$ & $76(37.3)$ & $67(38.7)$ & \\
\hline Very important & $203(50.6)$ & $108(52.9)$ & $95(54.9)$ & \\
\hline
\end{tabular}

Note: ${ }^{*} p$ value $<0.05$ 


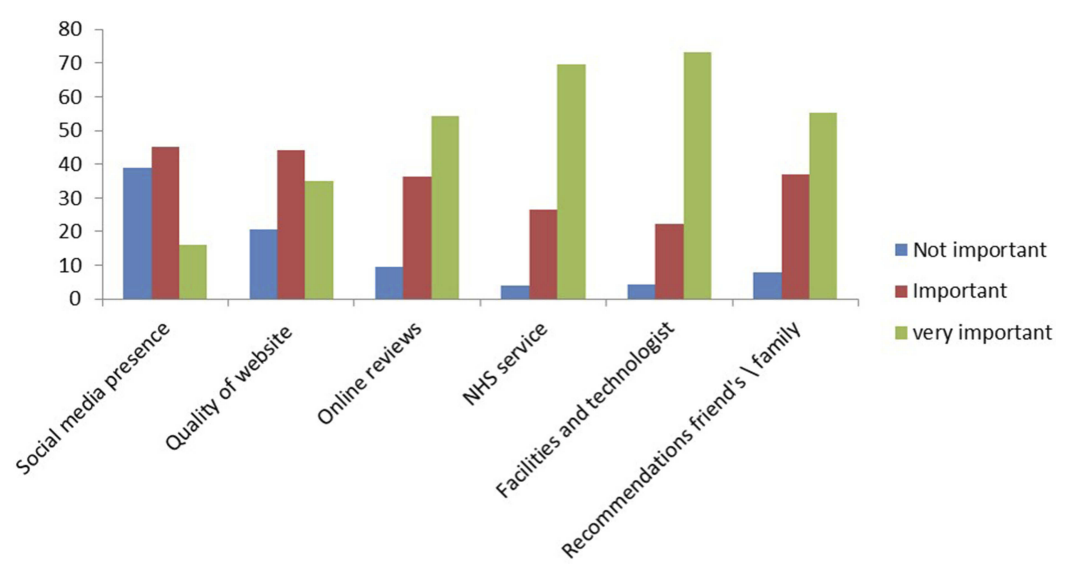

Figure I Factors that are most important to patients when choosing a dental practice.

the other hand, males were more interested in the special offer, awards, and numbers of likes.

\section{Discussion}

Our results indicated that facilities and technology, the qualifications of the dentist, and the positivity of reviews were the most important factors for patients in city of Jeddah, and females were more likely to be affected by social networking sites than males. Recently, it has been reported in numerous studies that social media is playing a significant role in healthcare. ${ }^{10,11}$ However, few studies have investigated the relations between social media and dentistry, and to our knowledge this is the first research talking about the city of Jeddah.

One of the important factors for dental practitioners to maximize their income is the ability to adapt to and follow modern dentistry as well as changes in consumer demographics, attitudes and preferences. There are several factors that may enhance these marketing strategies, in addition to clinical skills, and one of them is social media. In this study, we were concerned about the factors that might give more interest to patients when using social media platforms for a dental practice and whether or not it would make a difference in their opinion in choosing a dental practice. ${ }^{11}$

Moreover, our research indicated that social media sites have an important role in improving the patientdentist relationship. It discloses interesting insights related to attitudes toward dental social media. For example, females were more likely to be active than men; it has been known in the literature that females use social media more than males. ${ }^{12}$ In a survey, Hanna Krasnova et al investigated how gender influences continued intention to use social networking sites. They found females are using social media platforms more than males, due to their emotional volatility (they like to keep close ties and gain social information). While males tend to be inspired by skills to gain general information. ${ }^{13}$

Another factor is the time use. A Nielsen study reported that females use about 10 mins social networking daily through the mobile web, or through apps, whereas males spend less than 7 mins. ${ }^{12,13}$ This factor may explain why females tended to be more interested in having a social media platform for a dental practice, compared with males, as the results have revealed.

Social media was overall potentially effective to engage and obtain new patients. ${ }^{9}$ It has been mentioned that the role of dentists in social media was limited in attracting patients into a dental practice. ${ }^{14}$ Facilities and technology of the dental practice was the most important factor, since this technology might help them to provide the latest and the most updated treatment, and monitor their status or appointments. ${ }^{6}$ While the presence of social media and communication between patients and clinicians was the least important factor in our sample as shown in the result, the reason might be that both dentists and patients remain somewhat cautious to connect with each other as friends on social media. This is in line with the recommendations of a study entitled, "How doctors view and use social media: a national survey."14

Most of the patients were concerned about the positivity of the reviews when they visit a social media account for a dental practice. According to Forbes, the negativity of online reviews prevented $94 \%$ of consumers from visiting a practical business. ${ }^{15}$ With that being said, the positivity of online reviews has a better impact on a dental clinic. The qualifications of the dentist is another important factor. Patients might not fully understand the dentist 
Table 4 Frequency And Percentage Of Factors Related To Looking At A Social Media Account For A Dental Practice

\begin{tabular}{|c|c|c|c|c|}
\hline Variable & All $N(\%) ~ N=40$ I & Male $N(\%) \quad N=218$ & Female $N(\%) \quad N=\mid 83$ & $P$ value \\
\hline $\begin{array}{l}\text { Qualification of dentist } \\
\text { Not important } \\
\text { Important } \\
\text { Very important }\end{array}$ & $\begin{array}{l}30(7.5) \\
121(30.2) \\
226(56.4)\end{array}$ & $\begin{array}{l}21(10.3) \\
72(35.3) \\
111(54.4)\end{array}$ & $\begin{array}{l}9(5.2) \\
49(28.3) \\
115(66.5)\end{array}$ & $0.002^{*}$ \\
\hline $\begin{array}{l}\text { Positivity of reviews } \\
\text { Not important } \\
\text { Important } \\
\text { Very important }\end{array}$ & $\begin{array}{l}29(7.2) \\
122(30.5) \\
226(56.4)\end{array}$ & $\begin{array}{l}23(I I .3) \\
6 I(29.9) \\
120(58.8)\end{array}$ & $\begin{array}{l}6(3.5) \\
61(35.3) \\
106(61.3)\end{array}$ & $0.019 *$ \\
\hline $\begin{array}{l}\text { Awards } \\
\text { Not important } \\
\text { Important } \\
\text { Very important }\end{array}$ & $\begin{array}{l}|2|(30.2) \\
\mid 58(39.4) \\
98(24.4)\end{array}$ & $\begin{array}{l}63(30.9) \\
77(37.7) \\
64(31.4)\end{array}$ & $\begin{array}{l}58(33.5) \\
81(46.8) \\
34(19.7)\end{array}$ & $0.010^{*}$ \\
\hline $\begin{array}{l}\text { Original interesting content } \\
\text { Not important } \\
\text { Important } \\
\text { Very important }\end{array}$ & $\begin{array}{l}81(20.2) \\
175(43.6) \\
123(30.7)\end{array}$ & $\begin{array}{l}47(23) \\
86(42.2) \\
71(34.8)\end{array}$ & $\begin{array}{l}34(19.7) \\
87(50.3) \\
52(30.1)\end{array}$ & 0.056 \\
\hline $\begin{array}{l}\text { Before and after image } \\
\text { Not important } \\
\text { Important } \\
\text { Very important }\end{array}$ & $\begin{array}{l}60(14.9) \\
134(33.4) \\
183(45.6)\end{array}$ & $\begin{array}{l}44(21.6) \\
73(35.8) \\
87(42.6)\end{array}$ & $\begin{array}{l}16(9.2) \\
61(35.3) \\
96(55.5)\end{array}$ & $0.00 I^{*}$ \\
\hline $\begin{array}{l}\text { Special offers } \\
\text { Not important } \\
\text { Important } \\
\text { Very important }\end{array}$ & $\begin{array}{l}43(10.7) \\
133(33.1) \\
201(51.1)\end{array}$ & $\begin{array}{l}24(I I .8) \\
70(34.3) \\
110(53.9)\end{array}$ & $\begin{array}{l}19(11) \\
63(36.4) \\
91(52.6)\end{array}$ & 0.060 \\
\hline $\begin{array}{l}\text { Number of likes } \\
\text { Not important } \\
\text { Important } \\
\text { Very important }\end{array}$ & $\begin{array}{l}129(32.2) \\
144(35.9) \\
104(25.9)\end{array}$ & $\begin{array}{l}64(31.4) \\
80(39.2) \\
60(29.4)\end{array}$ & $\begin{array}{l}65(37.6) \\
64(37) \\
44(25.4)\end{array}$ & $0.024 *$ \\
\hline
\end{tabular}

Note: ${ }^{*} p$ value $<0.05$

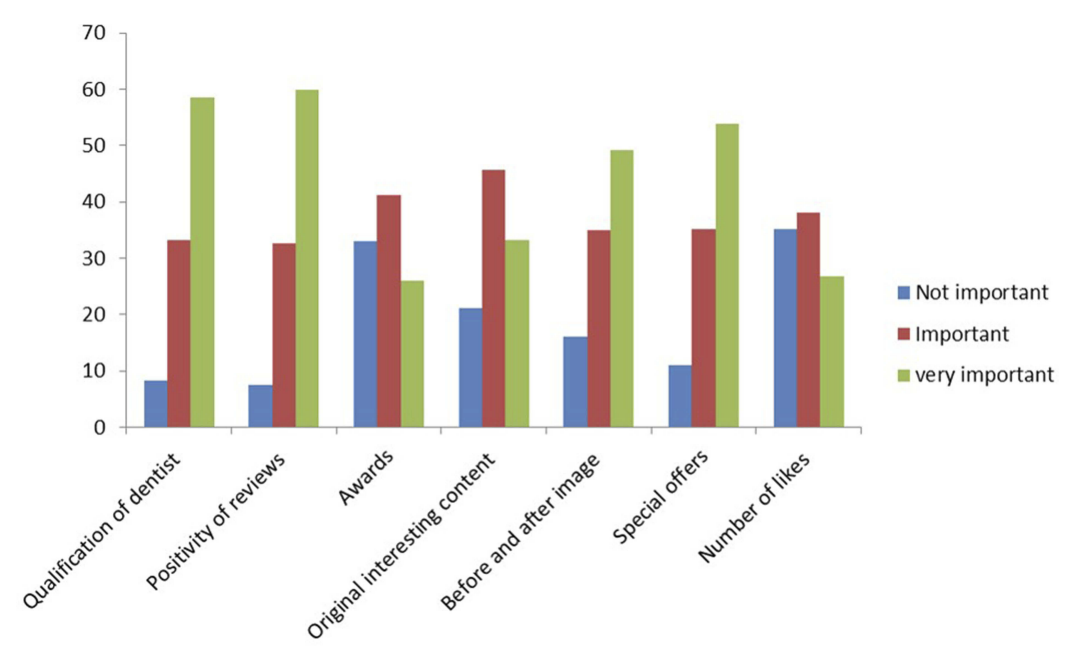

Figure 2 Factors that are most important to patients when looking at a social media account for a dental practice. 
degrees; however, knowing that his dentist is qualified will always count to him/her. ${ }^{9}$ Some factors like awards, special offers, and number of likes were more important factors for males mostly.

Although many dentists would like to share their research, interesting and published articles, interviews, medical fact and information in websites, original interesting content was not a statistical significant which may be due to difficulty of some of these contents. ${ }^{16-23}$

The quality of the web site is one of the important factors that influences patients and visitors and has a good impact on the dental practice. It helps to improve customers' respect for the professionalism of the clinic. ${ }^{24}$ Reliance on a web site to organize patients' appointments also helps to save time and manage the office well. There is even a link between the design of the clinic's website and the improvement of the patient's perception of it. ${ }^{16}$ Before-and-after images was also a major factor, especially among females. In fact, most of dental advertisements relied on before-and-after photos, because they give an overall esthetic and quality results that patients desire. ${ }^{25}$

This research was conducted in one place. As a result, there was no diversity of social classes. Nevertheless, it included middle class people. In spite of that, data from all participants were collected through an interview, making participants' answers more accurate. In addition, we have social media users only, it will be more interesting to compare between social medial users versus not. We suggest that the next research include various types of social classes and measure the different specialties of dentistry and the extent of people's interest to search for them.

\section{Conclusion}

Women were more likely to be affected by social networking sites than men were. This can affect their decision to choose their dentist. In addition, facilities and technology at the clinic, the qualifications of the dentist, and the positivity of reviews were the most important factors related to patients' choosing a dental practice or looking at a social account. Therefore, the presence of the dentist on social networking sites and the correct interaction with them is important to reach new patients and communicate with former patients.

\section{Acknowledgements}

This project was funded by the Deanship of Scientific Research (DSR), King Abdulaziz University, Jeddah, under grant number DF-051-165-1441. The authors, therefore, gratefully acknowledge the DSR for technical and financial support.

\section{Disclosure}

The authors report no conflicts of interest in this work.

\section{References}

1. Golder S, Ahmed S, Norman G, Booth A. Attitudes toward the ethics of research using social media: a systematic review. J Med Internet Res. 2017;19(6):e195. doi:10.2196/jmir.7082

2. Logghe HJ, McFadden CL, Tully NJ, Jones C. History of social media in surgery. Clin Colon Rectal Surg. 2017;30(4):233-239. doi:10.1055/s-0037-1604250

3. Alkhalaf AM, Tekian A, Park YS. The impact of WhatsApp use on academic achievement among Saudi medical students. Med Teach. 2018;40(sup1):S10-S14. doi:10.1080/0142159X.2018.1464652

4. Al-Khalifa HSG RA. The state of social media in Saudi Arabia's higher education. Int $J$ Technol Educ Marketing. 2013;3(1):65-76. doi:10.4018/ijtem.2013010105

5. Denecke K, Bamidis P, Bond C, et al. Ethical issues of social media usage in healthcare. Yearb Med Inform. 2015;10(1):137-147. doi:10.15265/IY-2015-001

6. Eysenbach G, Wyatt J. Using the Internet for surveys and health research. J Med Internet Res. 2002;4(2):E13. doi:10.2196/jmir.4.2.e13

7. Ventola CL. Social media and health care professionals: benefits, risks, and best practices. $P$ T. 2014;39(7):491-520.

8. Ajwa NA, S Al Mohsen, Kuwail A, AlOsaif, E. The impact of using social media networks on dental treatment marketing in Saudi Arabia: the practitioners and patient's perspectives. J Oral Health Dent Sci. 2018;2(4):1-10.

9. Parmar N, Dong L, Eisingerich AB. Connecting with your dentist on facebook: patients' and dentists' attitudes towards social media usage in dentistry. J Med Internet Res. 2018;20(6):e10109. doi:10.2196/10109

10. Sarringhaus MM. The great divide: social media's role in bridging healthcare's generational shift. J Healthc Manag. 2011;56(4):235-244.

11. Thielst CB. Social media: ubiquitous community and patient engagement. Front Health Serv Manage. 2011 Winter;28(2):3-14.

12. Duggan MB J. The Demographics of Social Media Users - 2012. Pew Reseach Center; 2013. Accessed 2018.

13. Krasnova H, Veltri NF, Eling N, Buxmann P. Why men and women continue to use social networking sites: the role of gender differences. $J$ Strategic Inf Sys. 2017;26(4):261-284. doi:10.1016/j.jsis.2017.01.004

14. Brown J, Ryan C, Harris A. How doctors view and use social media: a national survey. $J$ Med Internet Res. 2014;16(12):e267. doi:10.2196/jmir.3589

15. Otar C How review sites can affect your business (and what you can do about it). 2018.

16. Khanbodaghi A, Natto ZS, Forero M, Loo CY. Effectiveness of interprofessional oral health program for pediatric nurse practitioner students at Northeastern University, United States. BMC Oral Health. 2019;19(1):170. doi:10.1186/s12903-019-0861-y

17. Natto ZS, Hameedaldain A. Methodological quality assessment of meta-analyses and systematic reviews of the relationship between periodontal and systemic diseases. J Evid Based Dent Pract. 2019;19(2):131-139. doi:10.1016/j.jebdp.2018.12.003

18. Natto ZS, Abu Ahmad RH, Alsharif LT, et al. Chronic periodontitis case definitions and confounders in periodontal research: a systematic assessment. Biomed Res Int. 2018;2018:4578782. doi:10.1155/2018/ 4578782

19. Natto ZS, Almeganni N, Alnakeeb E, Bukhari Z, Jan R, Iacono VJ. Peri-implantitis and peri-implant mucositis case definitions in dental research: a systematic assessment. J Oral Implantol. 2019;45(2):127131. doi:10.1563/aaid-joi-D-18-00097 
20. Natto ZS, Yaghmoor W, Bannuru RR, Nevins M. Identification and efficacy ranking of allograft and xenograft for extraction and ridge preservation procedures. Int $J$ Periodontics Restorative Dent. 2017;37(5):e253-e260. doi:10.11607/prd.3323

21. Bonino F, Steffensen B, Natto Z, Hur Y, Holtzman LP, Weber HP. Prospective study of the impact of peri-implant soft tissue properties on patient-reported and clinically assessed outcomes. J Periodontol. 2018;89(9):1025-1032. doi:10.1002/JPER.18-0031

22. Natto ZS, Parashis A, Steffensen B, Ganguly R, Finkelman MD, Jeong YN. Efficacy of collagen matrix seal and collagen sponge on ridge preservation in combination with bone allograft: a randomized controlled clinical trial. J Clin Periodontol. 2017;44(6):649-659. doi:10.1111/ jcpe. 12722
23. ALHarthi SSY, Natto ZS, Midle JB, Gyurko R, O’Neill R, Steffensen B. Association between time since quitting smoking and periodontitis in former smokers in the National Health and Nutrition Examination Surveys (NHANES) 2009 to 2012. J Clin Periodontol. 2019;90 (1):16-25. doi:10.1002/JPER.18-0183

24. Al Hila AAAS MJ, Abu-Naser SS. The effectiveness of a website to improve the effectiveness of time management for employees in the beauty dental clinic. Int J Acad Inf Sys Res. 2018;2(5):23-52.

25. Nelson KL, Shroff B, Best AM, Lindauer SJ. Orthodontic marketing through social media networks: the patient and practitioner's perspective. Angle Orthod. 2015;85(6):1035-1041. doi:10.2319/ 110714-797.1

\section{Publish your work in this journal}

Patient Preference and Adherence is an international, peer-reviewed, open access journal that focusing on the growing importance of patient preference and adherence throughout the therapeutic continuum. Patient satisfaction, acceptability, quality of life, compliance, persistence and their role in developing new therapeutic modalities and compounds to optimize clinical outcomes for existing disease states are major areas of interest for the journal. This journal has been accepted for indexing on PubMed Central. The manuscript management system is completely online and includes a very quick and fair peer-review system, which is all easy to use. Visit http:// www.dovepress.com/testimonials.php to read real quotes from published authors. 